\title{
(LEGO BUILDING TECHNIQUE): AN INNOVATIVE PROPOSED STRATEGY IN TEACHING FASHION DESIGN PRACTICAL COURSES
}

\author{
Rehab Ragab Mahmoud Hassaan \\ Prof. Dr. University of Nizwa, SOLTUANATE of OMAN, rehab.ragab@unizwa.edu.om
}

\begin{abstract}
The Objective of the current study is to investigate effectiveness of using a new strategy which is founded by the researcher and had been called (Lego Building Technique), proposed strategy appropriates for practical fashion courses such as: hand embroidery, machine embroidery, fabrics dyeing, fabrics printing and painting, textile structure and design, hand weaving, hand crochet and tricot and all hand crafts courses. The proposed strategy (Lego Building Technique) had been launched through the experience of teaching hand Embroidery course for Nizwa University students- Fashion Design Program Autumn term/2020. The final project of the course -after teaching and learning hand embroidery stitches- was focusing on the goal of the fashion program which is represented in enhancing the creativity skills of designing fashion, the researcher/ course professor proposed a project of embroidering some cut motifs of felt material, then gather embroidered motifs on a foam mannequin in many designs, selecting the best design or structure, finally attach the embroidered felt motifs together for forming the selected structure by the student/designer producing a unique fashion piece. Thus the project which represents the new proposed strategy (Lego Building Technique) achieved three main goals, first: verification of accessing embroidering skills for the students, second: enhancing creativity thinking skills for the students as fashion designers, third: enhancing the employing of the accessed skills in creating unparalleled fashion. The results -executed designs- of the experience had been evaluated through a rating scale and the proposed strategy had been evaluated through a questionnaire. From this point the proposed strategy can be generalized in many other practical courses. The researcher used descriptive and experiment methodologies for the procedures and accessing the statistic results of the study. The study recommends adopting the proposed strategy in teaching practical courses in Fashion Design Programs.
\end{abstract}

Keywords: Lego Building Technique, fashion design program, practical fashion courses, hand embroidery, embroidered felt motifs, motifs forming, innovative fashion.

\section{INTRODUCTION}

Faculty members are responding to pressures to be more responsive to students' needs and more concerned about how well students are prepared to assume future societal roles. Faculty are already feeling the pressure to lecture less, to make learning environments more interactive, to integrate technology into the learning experience, and to use best learning strategies when appropriate. Some of the more prominent strategies are lecture, case method, discussion, active learning, cooperative learning, integrating technology and distance learning. The researcher as a teacher of fashion design courses for 25 years already used many of these mentioned strategies and more, through the experience of teaching (Hand Embroidery) for University of Nizwa students- College of Arts and Sciences- Department of Education and Humanities 
Culture- Fine Art Program- Speciality of Fashion Design- First/ Autumn Term 2019/ 2020 the researcher/ professor of the course reached to a new strategy, named it "Lego Building Technique".

Strategy, in general can be defined as the use of means to achieve goals, meaning that the strategy is a framework guiding the method of work and a guide to its movement. The teaching strategy is defined as regular and sequential procedural steps that are comprehensive, flexible and take into account the nature of the learners, as well as taking the available capabilities into account, with the aim of achieving the desired learning outcomes. "A teaching strategy is the method you use to convey information to your students." (Goodwin, 2018).

A good strategy has specifications, namely: the comprehensiveness of all possibilities of the educational situation - flexibility as it can be used in other classes - its relevance to the objectives of teaching - taking into account the individual differences between the learners - taking into account the capabilities available at the university. And it includes a group of ingredients, which are: Teaching objectives - teacher steps - used methods - educational atmosphere and finally the students' response.

The current study aims to establish an innovative strategy in teaching practical courses of fashion design programs, to be achieved through the proposed strategy: skills development - the development of creative and critical thinking - the encouragement of experiential learning and producing of innovative fashion.

\section{OBJECTIVES}

The study aims to establish a new strategy for teaching practical courses in fashion design programs, so that this strategy achieves three main objectives:

1- Verifying the acquisition of basic skills in the course.

2- Enhancing students 'innovative thinking skills as fashion designers.

3- Producing innovative fashion.

\section{SIGNIFICANCE}

1- Developing new teaching strategies would develop the educational process in universities.

2- The proposed strategy can be applied in other programs specialized in teaching Design Programs.

3- The new proposed strategy "Lego Building technique" benefits also fashion designers in producing unprecedented fashion with many perceptions.

\section{HYPOTHESIS}

1-The different practical skills of Hand Embroidery Course can be inserted into the production of Several miniature Lego units' successfully.

2-Innovative fashion can be produced through Lego unit's composition, named Lego Building Technique.

3-The teaching strategy named (Lego Building Technique) can be established to teach Hand Embroidery for students of the Fashion Design program.

4- The strategy (Lego Building Technique) can be applied to many practical courses in fashion design programs to achieve three goals: Application of course skills - Development of students' innovative thinking Production of innovative fashion.

\section{METHODOLOGY AND INSTURMENTS}

Descriptive Approach, in designing study instruments: - a scale for evaluating student production (Lego Fashion Rating Scale) - a questionnaire for the opinions of faculty members specialized in Fashion Design establishing the principles for the proposed strategy (Lego building technique)

Semi-experimental approach: When applying the strategy on a sample of (24) students, first semester / fall 2019/2020 at the University of Nizwa.

\section{RELIABILITY AND VALIDITY OF THE INSTURMENTS}

\subsection{Rating Scale) to Evaluate Students' Artworks in the Study Experiment:}

(Rating Scale) had been designed by the researcher on two axes that include (12) statements, (3) for the first axis and (9) for the second axis. The reliability of the scale was verified by presenting it to a group of 
supervisors, and then the scale was put in its final form. The validity of the scale was confirmed by Cronbach's alpha as 0.95 , which confirms its validity for application. The scale and the students' work were presented to a group of faculty members specializing in fashion, design and arts, and the evaluating was measured by Likert's five-point scale, so that the highest score for the scale is (60) and the lowest score is (12).

\subsection{Opinions Questionnaire of Faculty Members in the Proposed Strategy}

(Questionnaire) had been designed by the researcher on two axes that include (10) statements, (5) for the first axis and (5) for the second axis. The reliability of the questionnaire was verified by presenting it to a group of supervisors, and then the questionnaire was put in its final form. The validity of the questionnaire was confirmed by Cronbach's alpha as 0.90 , which confirms its validity for application. The evaluating was measured by Likert's five-point scale, so that the highest score for the questionnaire is (50) and the lowest score is (10).

\section{THE STUDY SAMPLE}

The study sample consisted of: (24) female students in the fashion design program - (7) faculty members in fashion design - (11) faculty members in curricular sciences and teaching methods.

\section{THEORETICAL FRAMEWORK}

\subsection{Strategy and Teaching Strategy}

\subsubsection{Strategy}

The strategy is to use the available resources, materials and means in the best way to achieve the desired goals, (1) When we try to achieve some objectives by any method it becomes strategies; (2) strategy is actually a combination of different method; (3) for E.g. Lecture or textbook or question answer method can be never be used separately; (4) it is a macro approach; (5) it considers teaching as science; (6) its purpose is to create conducive learning environment; (7) it is based on modern theories of organization; (8) (predetermined objectives, becomes strategy); (8) behaviour of students and teachers and their mutual relationship. (Sputra, Abdul Aziz, 2014. 114)

\subsubsection{Teaching Strategies}

Also known as instructional strategies are methods that teachers use to deliver course material in ways that keep students engaged and practicing different skill sets. An instructor may select different teaching strategies according to unit topic, grade level, class size, and classroom resources. Many learners of instructional strategies are employed to achieve teaching and learning goals and support different kinds of students. Specific strategies can also be employed to teach particular skills. (Kathy, 2020)

\subsection{3 “Lego Building Technique" as a Teaching Strategy}

It is an educational activity that is particularly concerned with preparing students of fashion design programs to create new fashion through their various practical courses. This teaching strategy relies on:

-linterest in thinking and imagining (developing an imaginary picture of the final design based within building Lego units .

- Flexibility in implementation (accepting alternatives in plastic solutions).

- Sharing with Colleagues (More than one student with their Lego units can participate in the production of one fashion item).

\subsubsection{The Proposed Strategy for Practical Courses is as Follows}

- Choosing a theme for the applied project through discussion between the professor and students.

- Each student selects some basic skill techniques in the course through a free choice of techniques, tools and materials, then apply these skills or techniques in small pieces.

- The professor exchanges the Lego units among the students and assigns them to create innovative designs by forming on the foam Mannequin with pins.

- The professor encourages students to create unprecedented designs. 
- Students analyze and critique each other's designs.

- At the end, each student gets back his Lego units, makes a final design with his own personal vision, and fixes the Lego units together by hand sewing or machine.

-Displaying the students' work at the end of each semester / every practical course in a collective exhibition.

\subsection{Fashion Design Program}

At University of Nizwa, College of Arts and Sciences, Education and Humanities Department, Fine Art Specialty, Fashion Design Program is a program of (132) credit hours, divided to (27) CR hours University requirements/ selection, (20) CR hours College requirements/ selection, (19) CR hours Educational requirements, (66) CR hours Major requirements/ selection. Course of (Hand Embroidery) is one of the major requirements of fashion Design courses.

Fashion Design Program has (10) main outcomes, five of them related of skills development, means practical parts of the courses have to saturate these objectives and achieve these achievements. The skills outcomes as following:

-The student will be able to master technical skills and employ them in artistic works.

-The Students can use different types of tools, materials and techniques to produce a successful fashion.

-The student employs different types of artistic attitudes in building innovative artworks.

-The student can describe, critic and analyze the artistic values.

-The student uses various research resources and databases of information in the applications of technologies related to the fashion field. (University of Nizwa bylaw)

\section{3 (Hand Embroidery) Course}

The course is divided into two parts. The first is theoretical. It includes the study of hand embroidery history and the study of embroidery on different traditional costumes, including the Omani traditional costumes for men and women. And the applied part includes the basic set of stitches as follows: running stitch- back stitch- satin stitch- stem stitch- seed stitch- chain stitch- fishbone stitch- Cretan stitch- blanket stitch- long\& short stitch. And embroidery with additions, such as embroidery with pearls, crystal, buttons and plastic, wooden and metal beads. The course professor also allowed the students to add some innovative stitches in the applied projects.

\section{4. "Lego Building Technique"}

\subsubsection{The strategy of "Lego Building Technique" Considerations}

The proposed strategy of "Lego Building Technique" in the current study for teaching practical courses of fashion design programs depends on five considerations:

First: The goal of teaching fashion program students some of the skills associated to fashion design such as printing, embroidery, dyeing and others is widening the student's skills of the possibility of benefiting from the applications of these art courses in the field of fashion. Rather, they are linked to fashion design to a large extent.

Second: The fashion designer is not a required to produce any products but fashion pieces through learning these courses, not table linens, scarves, Curtains, or any products, but fashion.

Third: After learning the basics of skills in these courses, it is possible to employ those basics in developing innovative thinking of designing unprecedented fashion.

Fourth: Each or some of the Lego units contains the skills that the student must master in the course.

Fifth: Lego technique is based on dealing with many repeated miniature Lego units to build and implement a piece of fashion which is formed on a foam mannequin.

Therefore this strategy tests the student's capacity to practice course skills and at the same time helps the student directly to employ these skills in the production of innovative fashion, thus enhancing the student's personality as an innovative fashion designer after graduation. 


\subsubsection{Principles of Lego Fashion Composition}

There are some principles of the fashion composition within Lego Building Technique, (unity), (harmony), (rhythm) and (proportion) comes automatically because of using one theme for all Lego units, there are some other basics should be put into account, as following:

- Dominate \& Subordinate: When one or more of the design elements are emphasized measurably more than any others, they are dominant (have the greatest visual weight, greatest number, or has the most influence). When dominant/subordinate is used together, they create stability and order. Subordination is simply any of the elements that are emphasized less than the dominant ones

- Repetition with Variation: Repetition means to repeat one or more of the Lego units to build the design structure. Variation means to change one or more of the Lego unit's shapes.

-Overlapping: is when shapes are in front of other shapes. Two principle outcomes of overlapping shapes within a composition are: 1) make shapes either dominant or subordinate and 2) to vary and repeat the shape.

- Balance: Refers to the way the Lego units are arranged within the format to create a feeling of stability or harmony. When considering the idea of balance, it is very helpful to divide any composition in half, using a central illusion line. If the shapes are mostly the same on each side of this line, the composition is symmetrical. If they are different on each side of the central line, they are asymmetrical. (Bradely, 2018, P.209: 259)

Contrast: as a principle of composition, differentiates line, value, shape, texture, and colour. It helps to create dominant areas, emphasizing what is most important. Contrast makes shapes more clear. In current project of embroidered felt units, the students used the principle of contrast in selecting felt colours and threads colours.

- Alignment: As a principle of composition, is used to help place or organize the shapes within the format and give it a unified structure, for example shapes are placed horizontally and vertically, above and below each other, to help create stable and consistent structure. (Lidwell, Holand, Butler, 2003, P.22:39)

- Superposition: When installing a small unit on top of another larger unit.

- Gradation: Scaling is the sizes between large and small of the LEGO Component units for the design.

- Focal Point: The focus of the vision in the implemented fashion design should be directed to the parts of applying the course skills.

\section{EXPERIMENTAL FRAMEWORK}

The researcher in this experience depends on articulating the experimental side indicating the objectives, procedures and application analysis. The main objective of this experiment is to find out a new strategy which can be applied in all practical courses of Fashion Design Program, and measure the experiment outcomes.

\subsection{Felt Fabric}

Felt is a non-woven fabric composed of interlocked fibres. There are two main types of felt, first: pressed felt, which is produced by applying heat moisture and friction to entangle and bind fibres together, second: needle felt, which mechanical operation plays the main role to interlock the fibres together. This is why felt can be cut without fraying. (Atifi, 2016,) Felt can be made with both natural fibres, such as wool, and synthetic fibres like acrylic and polyester. In general, pressed wool felts are considered the highest quality of felt fabric. (Ammayappan, Moses, Shunmugam. 2006. P. 617)

Felt can be obtained in various lengths, widths and thicknesses. The current project used the felt sheets which is commonly available in a wide spectrum of colours. Felt retains water and other liquids. Felt is also durable and resistant to wear and tearing. (Giles, 2010, P.5) (Houghton, 2018, P13)

A non-woven fabric, felt holds its edges and will not unravel when cut. These advantages, along with its naturally beauty and versatility, make felt the perfect material for the designer and crafter. In fact, felt is well suited for use in every sector and the researcher found it the perfect fabric for experiencing the "Lego Building Technique" in (Hand Embroidery) course. 


\subsection{Felt/Lego Cut Patterns}

\subsubsection{Experiment Constants and Variables}

Although there are many felting techniques and patterns of construction to create unique fashion pieces through felt, from simple scarves through hats to jackets and coats, but the applied project of the current study is concentrating on making, practicing and designing creative fashion corsages through embroidering the felt cut patterns. The professor guided the students to select some shapes of the patterns, including (geometric shapes- natural abstracted shapes as leaves- Omani traditional motifs).

The experimental activity was carried out in this study depending on a set of constants and variables, which represent the limits of the practical experiment. As follows:

Table 1: Lego Fashion experiment constants and variables

\begin{tabular}{|c|c|}
\hline Experiment constants & Experiment variables \\
\hline $\begin{array}{c}\text { - Using } 2 \text { mm felt material as a basic material for } \\
\text { embroidery and building Lego miniature units. }\end{array}$ & $\begin{array}{c}\text { - Colours and shapes for Lego miniature units. } \\
\text {-Formation style (superposition- overlapping- } \\
\text {-The types of used stitches are the included ones in } \\
\text { the course, in addition to allowing the student to } \\
\text { implement innovative stitches. }\end{array}$ \\
$\begin{array}{c}\text { contrast- alignment- grading increase and } \\
\text { decrease- and other principles) }\end{array}$ \\
$\begin{array}{c}\text {-Forming the embroidered units as a corsage on } \\
\text { the foam mannequin, then choosing the best } \\
\text { formation at the end gather the units. }\end{array}$ & -Types and colours of embroidery threads. \\
\hline
\end{tabular}

\subsubsection{Experiment sample}

(24) Students of Hand Embroidery Course- fashion Design Program- Education and Humanities Culture Department- College of Arts and Sciences- University of Nizwa - Sultanate of Oman.

First / Autumn term 2019/ 2020.

\subsubsection{Experiment Procedures (classroom strategy steps)}

-Each student selects a set of shapes, and then chooses the colors and cuts out the felt patterns -supervised by the teacher

-The student designs and creates embroidery stitches on each shape separately- supervised by the teacher

- The instructor redistributes Lego units to students, asking for forming a corsage on the foam manniquen by each student.

-The instructor open discussion among the students/ designers about there creations.

- Each student restore his/her own miniature Lego units and constitute the fashion piece on the private taste.

-The student attaches the shapes on the foam mannequin with staples

-The student selects the best composition and attaches the embroidered units with each other.

\subsection{Hand Embroidery Stitches}

The theoretical part of the course includes embroidery history and samples of embroidered traditional costumes, practical part includes training of making some stitches, divided into:

- Classic basic stitches (running stitch- back stitch- satin stitch- stem stitch- seed stitch- chain stitch- fishbone stitch- Cretan stitch- blanket stitch- long\& short stitch).

- Embroidery with pearls, buttons and crystal beads

-New creative stitches form y the student, which is matching with the shape of cut shape.

\subsection{The creative Fashion Corsage (Lego Structure)}

Includes "Fig.1" to "Fig. 12" which represents some samples of the students Lego fashion within the current 
experiment of the proposed strategy "Lego Building Technique".
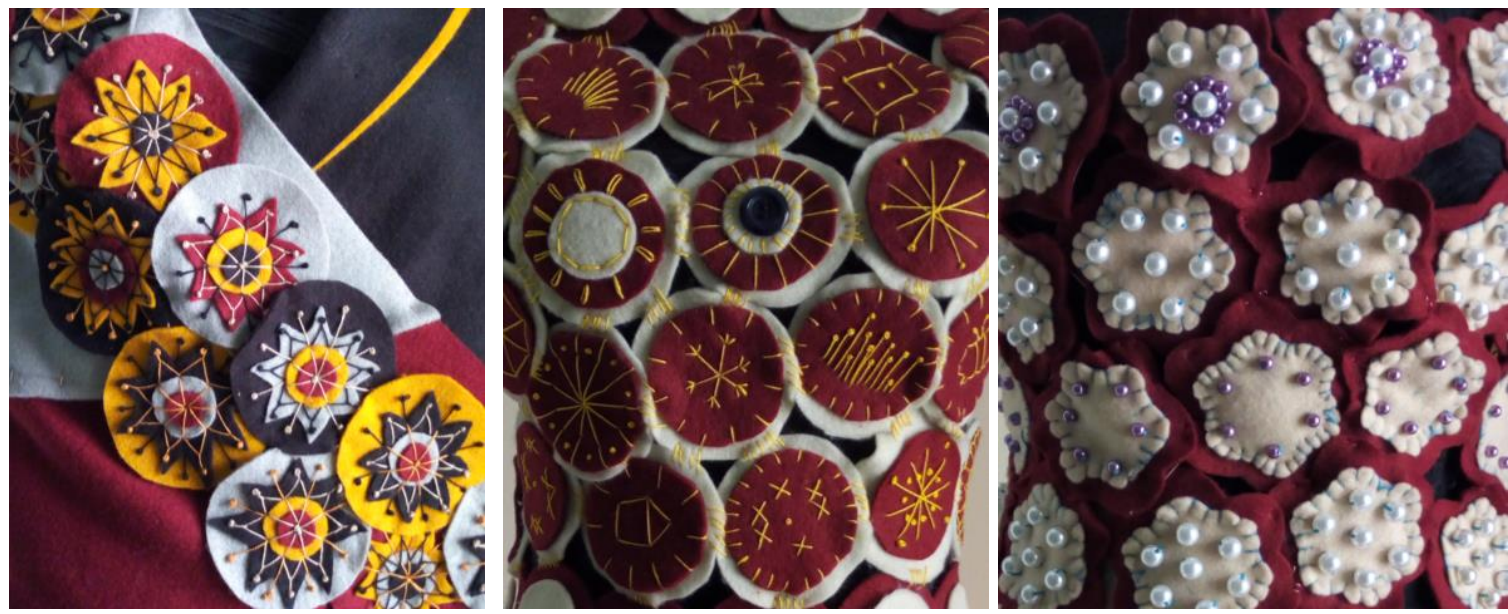

Fig. 1. 2. 3: Different hand embroidery stitches attached together in (Lego Building Technique) applying the strategy basics of Lego Fashion: superposition- overlapping- alignment-gradation- repetition.

Hand embroidery stitches: blanket stitch- pearl embroidery- innovative stitches by the students.
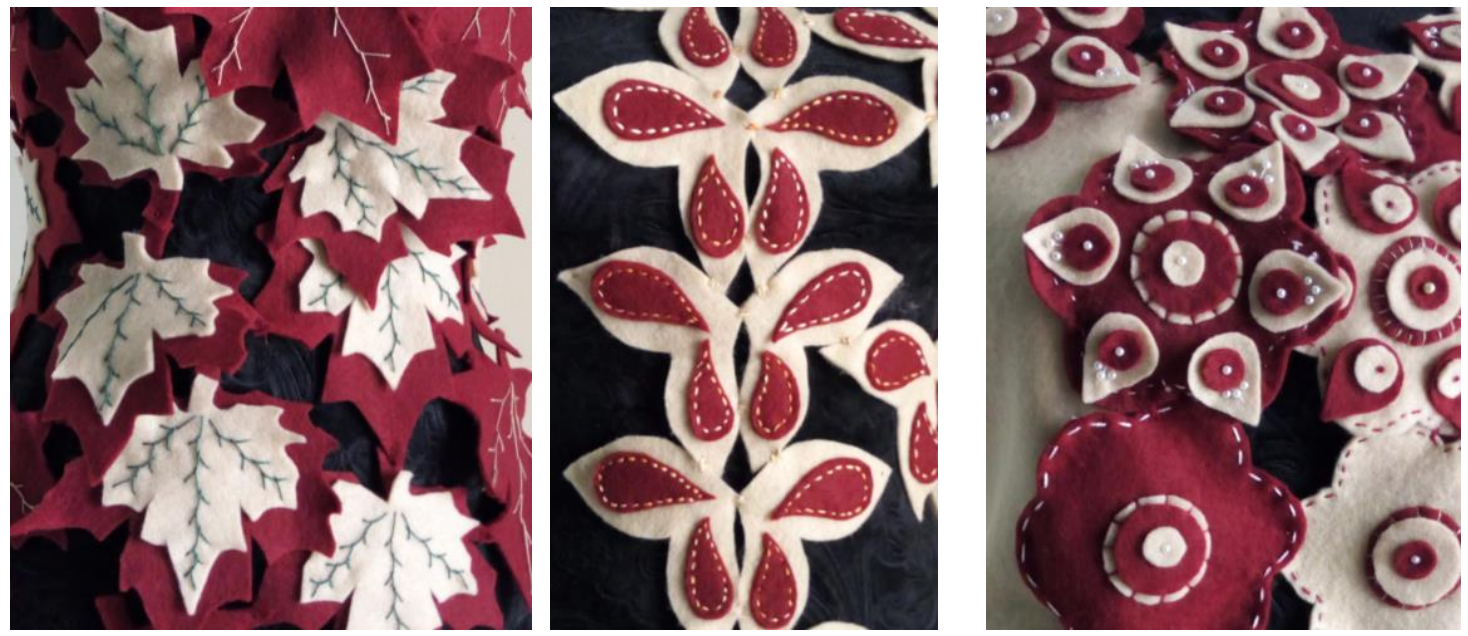

Fig. 4. 5. 6: Different hand embroidery stitches attached together in (Lego Building Technique) applying the strategy basics of Lego Fashion: superposition- overlapping- alignment-gradation- repetition.

Hand embroidery stitches: running stitch- pearl embroidery- Cretan stitch- blanket stitch.
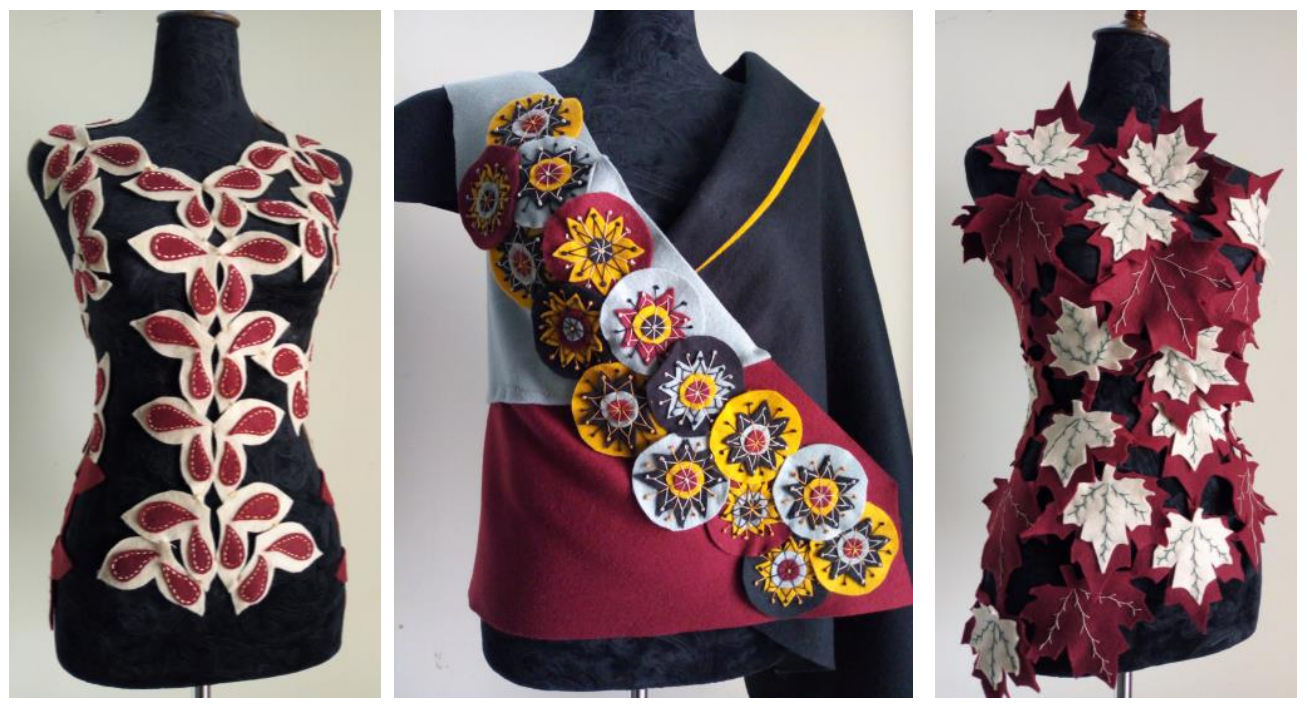
Fig. 7. 8. 9: Fashion Program students' projects of Hand Embroidery Course following "Lego Building Technique" strategy
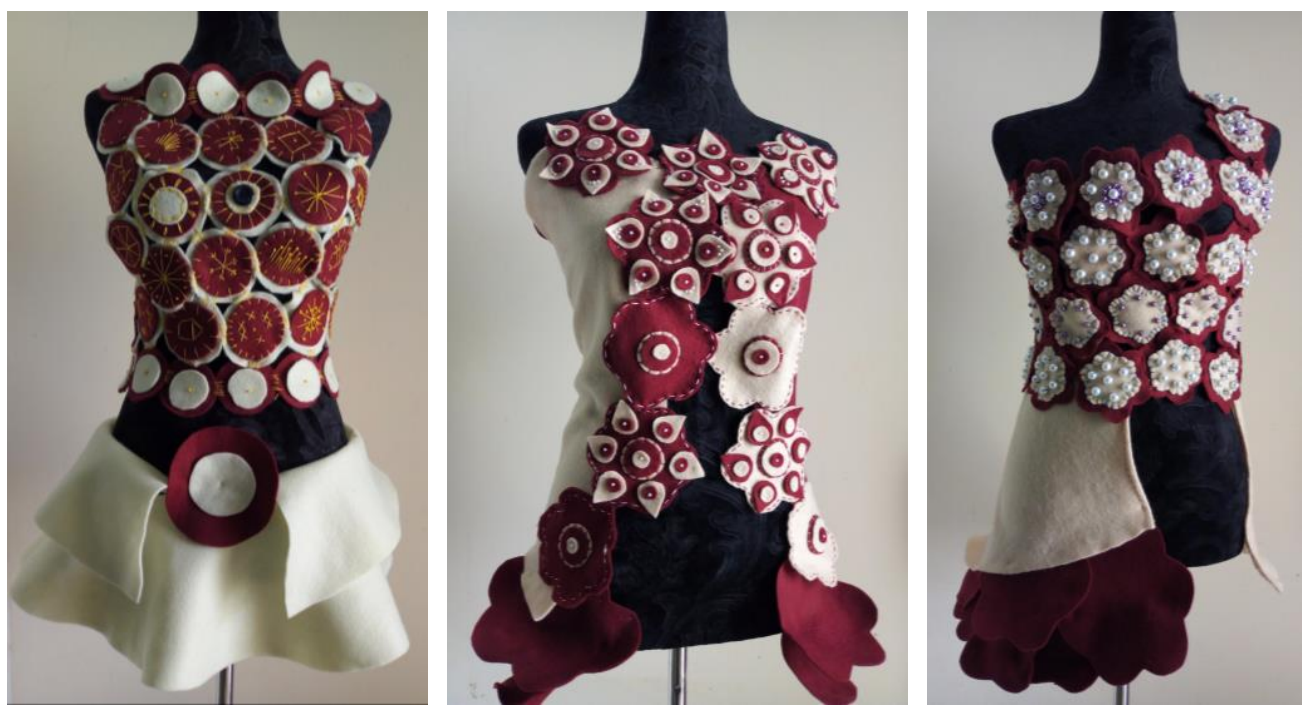

Fig. 10. 11. 12: Fashion Program students' projects of Hand Embroidery Course following "Lego Building Technique" strategy

\section{THE STUDY RESULTS}

First hypothesis: "The different practical skills of Hand Embroidery Course can be inserted into the production of several miniature Lego units' successfully". First axis of the Rating Scale represents the responding, as follows:

Table 2. Rating Scale: First axis: Aesthetics of one Lego unit

\begin{tabular}{|c|c|c|}
\hline Phrase & (SMA) & Proportion \\
\hline $\begin{array}{l}\text { - The single unit of Lego that consists the design is a miniature } \\
\text { model of applying practical skills of the course (Hand Embroidery) }\end{array}$ & 4.32 & $86.4 \%$ \\
\hline $\begin{array}{l}\text { - A single Lego unit is a miniature artwork that includes design } \\
\text { elements (point - line - colour - area - material - texture ...) }\end{array}$ & 4.02 & $80 \%$ \\
\hline $\begin{array}{l}\text { - The single Lego unit is a miniature artwork that achieves the } \\
\text { composition principles (unity - balance - rhythm - proportion - } \\
\text { contrast - compatibility ...) }\end{array}$ & 4.55 & $91 \%$ \\
\hline Total & 4.29 & $85.93 \%$ \\
\hline
\end{tabular}

Second hypothesis: "Innovative fashion can be produced through Lego unit's composition, named Lego Building Technique". Second axis of the Rating Scale represents the responding, as follows:

Table 3. Rating Scale: Second axis: Fashion within Lego Building Technique

\begin{tabular}{|c|c|c|}
\hline Phrase & (SMA) & Proportion \\
\hline - Lego fashion fulfils the principle of (Dominate and Subordinate) & 4.13 & $82.6 \%$ \\
\hline - Lego fashion fulfils the principle of (Repetition with Variation) & 4.56 & $91.2 \%$ \\
\hline - Lego fashion fulfills the principle of (Overlapping) & 4.25 & $85 \%$ \\
\hline
\end{tabular}




\begin{tabular}{|c|c|c|}
\hline$-\quad$ Lego fashion fulfils the principle of (Balance) & 4.7 & $94 \%$ \\
\hline$-\quad$ Lego fashion fulfils the principle of (Contrast) & 4.9 & $98 \%$ \\
\hline- Lego fashion fulfils the principle of (Alignment) & 5 & $100 \%$ \\
\hline - Lego fashion fulfils the principle of (Superposition) & 4.66 & $93.2 \%$ \\
\hline - Lego fashion fulfils the principle of (Gradation) & 4.3 & $86 \%$ \\
\hline - Lego fashion fulfils the principle of (Focal Point) & 4.1 & $82 \%$ \\
\hline Total & 4.51 & $90.2 \%$ \\
\hline
\end{tabular}

Third hypothesis: "The teaching strategy named (Lego Building Technique) can be established to teach Hand Embroidery for the students of Fashion Design program ". First axis of the questionnaire represents the responding, as follows:

Table 4. Strategy Questionnaire Measurement: First axis: The proposed Strategy Properties

\begin{tabular}{|c|c|c|}
\hline Phrase & (SMA) & Proportion \\
\hline $\begin{array}{c}\text { - The strategy is linked to the objectives of the course (Hand } \\
\text { Embroidery) }\end{array}$ & 4.25 & $85 \%$ \\
\hline $\begin{array}{c}\text { - The proposed strategy is inclusive for different educational } \\
\text { situations }\end{array}$ & 4.56 & $91.2 \%$ \\
\hline $\begin{array}{c}\text { - The strategy is flexible and can be used in more than one } \\
\text { classroom }\end{array}$ & 4.63 & $92.6 \%$ \\
\hline $\begin{array}{c}\text { - The strategy takes into account the individual differences between } \\
\text { the learners }\end{array}$ & 4.65 & $93 \%$ \\
\hline $\begin{array}{c}\text { - The strategy takes into account the capabilities available in } \\
\text { universities }\end{array}$ & 4.35 & $87.1 \%$ \\
\hline Total & 4.49 & $89.76 \%$ \\
\hline
\end{tabular}

Fourth hypothesis: "The strategy (Lego Building Technique) can be applied in many practical courses of fashion design programs to achieve three goals: Application of course skills - Development of students' innovative thinking - Production of innovative fashion ". Second axis of the questionnaire represents the responding, as follows:

Table 5. Strategy Questionnaire Measurement: First axis: The Implemented fashion through the proposed strategy (Lego building technology)

\begin{tabular}{|c|c|c|}
\hline Phrase & (SMA) & Proportion \\
\hline $\begin{array}{l}\text { - Designing and implementing the Corsage is a unique application of } \\
\text { the practical skills of the course (Hand Embroidery) }\end{array}$ & 4.55 & $91 \%$ \\
\hline
\end{tabular}




\begin{tabular}{|c|c|c|}
\hline - The implemented corsage is an innovative fashion design piece. & 4.65 & $93 \%$ \\
\hline $\begin{array}{l}\text { - The proposed strategy (Lego Building Technique) enhances } \\
\text { innovative thinking of the fashion program students }\end{array}$ & 4.28 & $85.6 \%$ \\
\hline $\begin{array}{c}\text { - The proposed strategy can be applied in more than one practical } \\
\text { course }\end{array}$ & 4.56 & $91.2 \%$ \\
\hline $\begin{array}{l}\text { - The experiment and suggested strategy can be applied in all } \\
\text { fashion design programs }\end{array}$ & 4.27 & $85.4 \%$ \\
\hline Total & 4.46 & $89.2 \%$ \\
\hline
\end{tabular}

\section{RECOMMENDATIONS}

The current study recommends adopting the proposed strategy (Lego building technology) in teaching practical courses in fashion programs such as printing, dyeing and drawing on fabric courses, textile compositions and machine embroidery courses, and all handicraft courses, because the results have demonstrated the ability of the proposed strategy to: 1 - Developing the skills targeted in the course.

2- Enhancing students' innovative thinking as fashion designers. 3- The production of innovative fashion.

\section{ACKNOWLEDGEMENT}

This research was financially supported by University of Nizwa.

\section{REFERENCE LIST}

Ammayappan, L. Moses, J. Shumugam, V. (2006). An Overview of the production of Nonwoven Fabric from Woolen Materials. Textile Research Journal, Vol 67, no8, PP 616: 618.

Atifi, L. (2016) .Felt and its properties". June, 27.

From: http://www.lilylatifi.com/en/news/flexible-materials/felt-and-its-properties. (11August 2020)

Bradely, S. (2018). Design Fundamentals: Elements, Attributes and Principles. Vanseo Design. Boulder. Colorado.

Giles, J.: (2010). Felt Fashion: Couture Projects from Garments to Accessories. Quarry Book.

Goodwin, J. (2018) top 10 Teaching Strategies to use in your Classroom. Magoosh.

From: https://schools.magoosh.com/schools-blog/top-10-teaching-strategies (16 August 2020)

Houghton, L. (2018). Felt Fashion: Creative and Inspirational Techniques for Felt Makers. Batsford. London.

Kathy, s. "What are teaching strategies". Effective Teaching Strategies.

From:https://study.com/teach/instructional-

strategies.html\#: :text=Teaching\%20strategies\%2C\%20also\%20known\%20as, and\%20practicing\%20 different\%20skill\%20sets.\&text=Specific\%20strategies\%20can\%20also\%20be,like\%20strategies\%20f or\%20problem\%20solving. (12August 2020)

Lidwell, W. Holden, K. Butler, J. (2003). Universal Principles of Design. Library of Congress. USA.

Saputra, J. B. Abdul Aziz, M. S. (2014). Teachin Strategies.

From: https://www.researchgate.net/publication/327433965_TEACHING_STRATEGIES (13 August 2020)

University of Nizwa bylaw. College of Arts and Sciences. Department of Education and Humanities Culture. 